腺リンパ腫を合併した両側耳下腺基底細胞腺腫例

\author{
吉村 勝弘・今中 政支・中村 雅宏 \\ 河田了·竹中 洋

\section{Bilateral Basal Cell Adenomas in the Parotid Glands Combined with Warthin's Tumor Unilaterally; A Case Report}

\author{
Katsuhiro Yoshimura, Masashi Imanaka, Masahiro Nakamura, \\ Ryo Kawata and Hiroshi Takenaka \\ (Osaka Medical College)
}

\begin{abstract}
We treated an extremely rare case of bilateral basal cell adenomas combined with Warthin's tumor in the left parotid gland. The patient was a 65 -year-old male who complained of swelling in the bilateral parotid areas. We removed bilateral parotid masses. Histopathological examination demonstrated adenoma and Warthin's tumor. The incidence of bilateral parotid tumors is rare, and synchronous tumors with different histopathological types in a single salivary gland are extremely rare.
\end{abstract}

Key words : basal cell adenomas, Warthin's tumor, bilateral parotid tumors, synchronous tumors

はじめに

基底細胞腺腫（basal cell adenoma）は，喠液腺良性腫 瘍としては比較的まれな組織型であり，その発生頻度は 約 $2 \sim 5 \%$ と報告されている1) 3). また耳下腺腫瘍は片 側性に発生することがほとんどで，両側に発生する腫瘍 としてはワルチン腫瘍が知られている.

今回われわれは, 両側耳下腺に基底細胞腺腫が発生し, また一側耳下腺にワルチン腫瘍が合併したきわめてまれ な 1 例を経験したので，若干の文献的考察を加えて報告 する。

\section{症例}

患者: 65 歳, 男性.

主訴 : 両側耳下部の腫脹.

既往歷：特記すべきことなし.

家族歴：特記す心゙きことなし。

現病歴：平成 6 年頃より両耳下部の腫脹を自覚してい たが，特に症状は認めなかったため放置していた。 右耳
下部腫脹が徐々に増大してきたため, 平成 7 年 10 月 12 日 当科を受診し, 平成 8 年3月 14 日手術目的に入院となった.

入院時現症 : 右耳下部に直径 $20 \mathrm{~mm}$ 大, 左耳下部に直 径 $10 \mathrm{~mm}$ 大の腫瘤を触知した. 両側とも弾性軟, 可動性 は良好で疼痛や顔面神経麻痻は認めなかった。

各種検查所見：超音波検查（以下，エコー）では，右 耳下腺内に直径 $18 \mathrm{~mm}$ 大, 左耳下腺内に直径 $9 \mathrm{~mm}$ 大の 低エコー域を認めた。いずれも内部均一で, 辺緣整であっ た. エコー下に施行された穿刺吸引細胞診（以下，FNA） では, 組織球が認められるのみで異型細胞は認められな かった. CT 検查では, 右耳下腺に直径 $12 \mathrm{~mm}$ 大と深葉 に直径 $6 \mathrm{~mm}$ 大の腫溜陰影を認めた。 また左耳下腺には 直径 $5 \mathrm{~mm}$ 大の腫瘤陰影を認めた（図 1).いずれも辺縁 整で, 右の $12 \mathrm{~mm}$ 大の腫瘤は辺縁が高吸収域で, 内部が 低吸収域を示し, $6 \mathrm{~mm}$ 大の腫瘤は内部が均一で等吸収 域を呈していた． 左の $5 \mathrm{~mm}$ 大の腫瘤は内部が均一で等 吸収域であった。テクネシウムによる唾液腺シンチグラ フィーでは，集積は認めなかった。 なお，血液検查では 


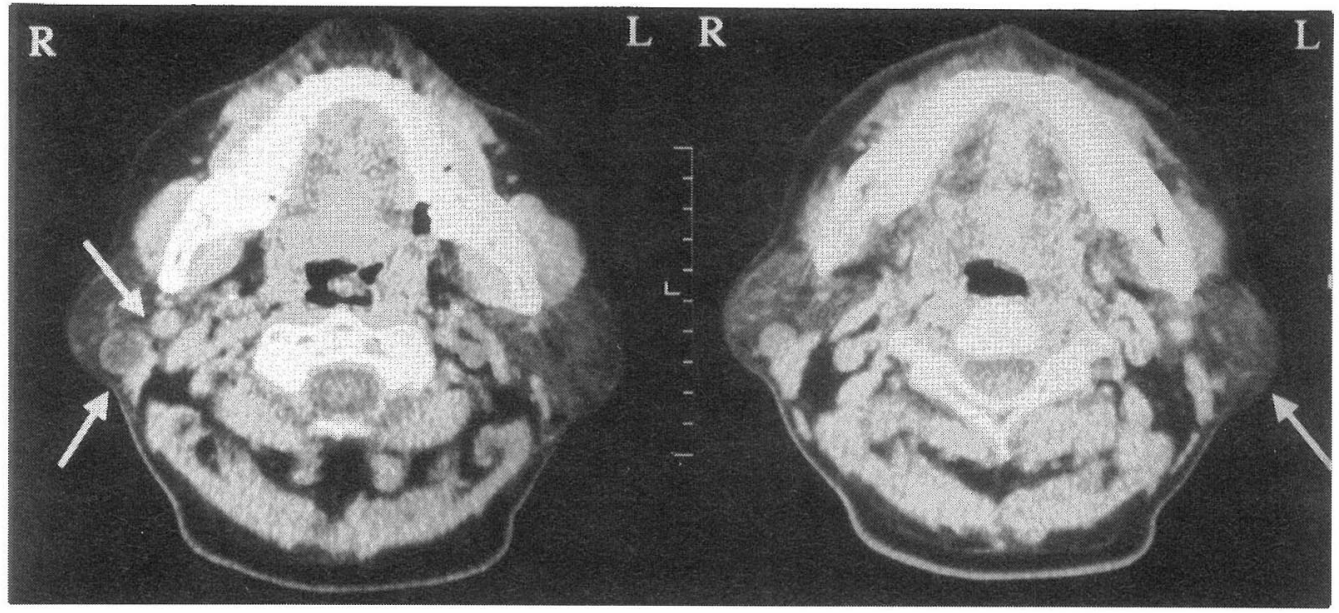

図 $1 \mathrm{CT}$ (単純) (平成 8 年)

右耳下腺に直径 $12 \mathrm{~mm}$ 大と $6 \mathrm{~mm}$ 大の腫瘤陰影 (矢印) を, 左耳下腺に直径 $5 \mathrm{~mm}$ 大の腫瘤陰影 (矢印) を認める。

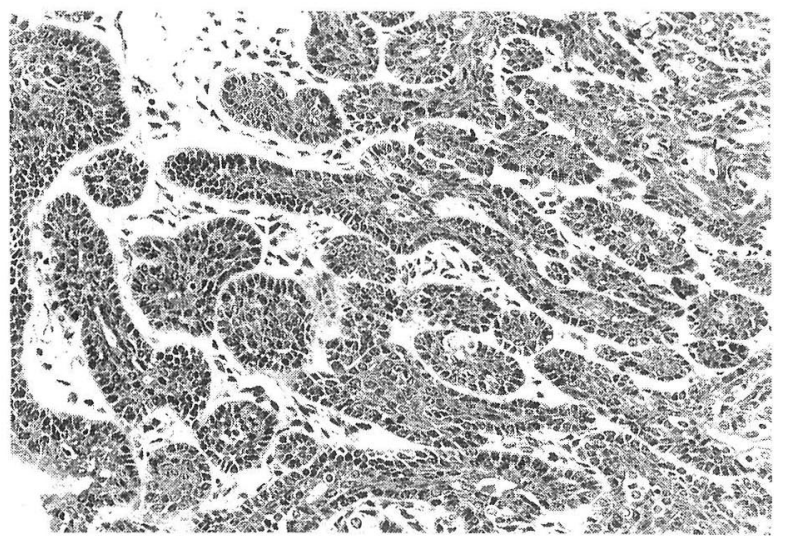

図 2 基底細胞腺腫（充実型）（HE 染色，3.3 320 倍）

異常は認めなかった。

入院後経過：平成 8 年 3 月 18 日, 増大傾向のみられた 右耳下腺腫瘍に対して手術を施行した，大きい方の腫瘍 が耳下腺浅葉に存在していたため，顔面神経煩筋枝と下 顎縁枝を確認保存し，まず浅葉部分切除を行った。深葉 の腫瘤は頸枝の外側加剥離し摘出した。病理組織検查 で，いずれも充実型の基底細胞腺腫と診断された（図 2)。 退院後経過：術後，全く顔面神経麻痺はなく経過良好 であったため, 平成 8 年 3 月 30 日退院となった。以後外 来で経過観察していたが, 平成 12 年 4 月頃より左耳下部 腫瘤の増大を認めるようになり,同年 9 月 13 日手術巨的 に入院となった。

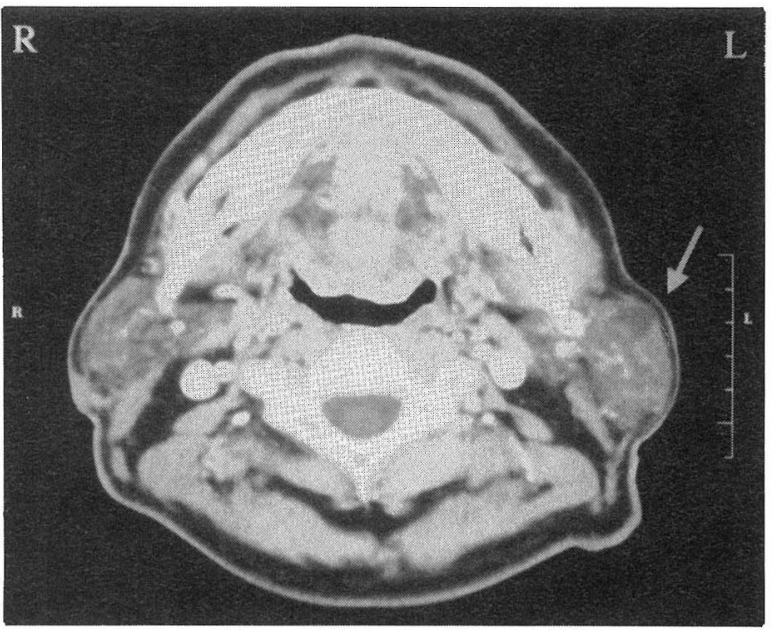

図 $3 \mathrm{CT}$ (造影) (平成 12 年)

左耳下腺内に約 $15 \mathrm{~mm}$ 大の辺縁整，内部が均一で造影効 果を受けない囊胞状の腫瘤陰影を認めた (矢印)。

入院時所見：左耳下部に $22 \times 18 \mathrm{~mm}$ 大の弾性軟，表 面平滑，可動性良好な腫瘤を触知した。疼痛はなく，顔 面神経麻痺も認めなかった。

各種検査所見：エコーでは, 左耳下腺内に約 $13 \mathrm{~mm}$ 大 の境界明瞭で内部が均一，後方エコーの増強を伴ら低エ コー域を認めた。造影 CT 検査では，左耳下腺内に約 $15 \mathrm{~mm}$ 大の辺縁整，内部が均一で造影効果を受けない囊 胞状の腫瘤院影を認めた（図 3)。テクネシウムによる唾 


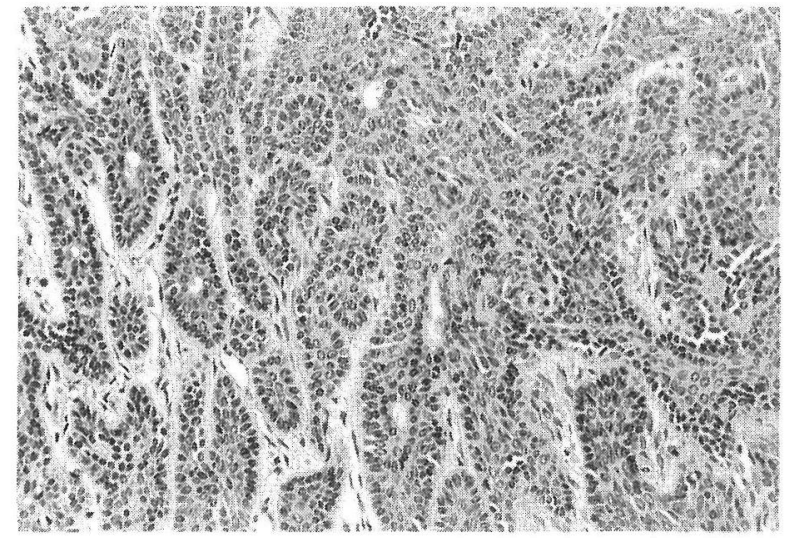

図 4 基底細胞腺腫（充実型）（HE 染色， $3.3 \times 20$ 倍）

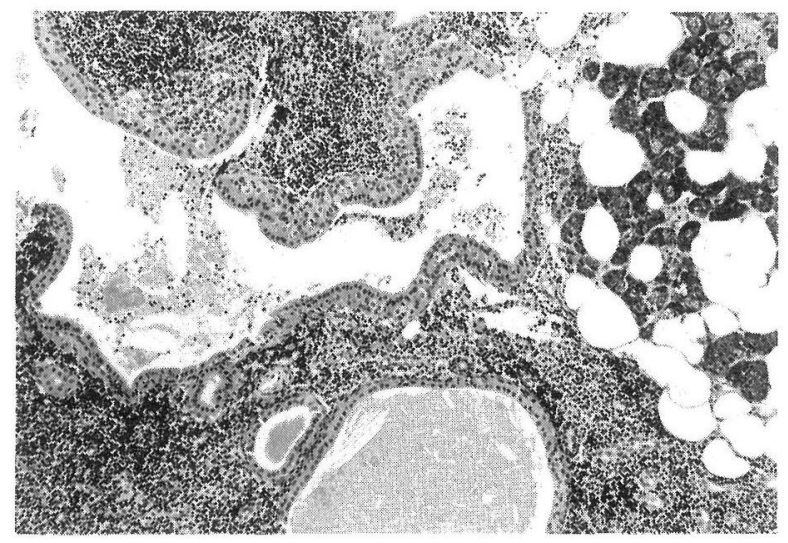

図 5 ワルチン腫瘍（HE 染色， $3.3 \times 10$ 倍）

液腺シンチグラフィーでは，同部に集積を認めた。なお， 右耳下腺に腫瘍の再発は認めなかった。

入院後経過：以上の検查結果よりワルチン腫盷を強く 疑い，平成 12 年 9 月 18 日, $\mathrm{S}$ 状切開にて左耳下腺腫瘍 摘出術を施行した。腫瘤は，顔面神経類筋枝々下顎縁枝 の中間に位置していたが神経との癒着はなく, 腫瘤周囲 に十分な正常耳下腺組織を付けて浅葉を摘出した。 術後 に一過性の顔面神経麻痺も認めなかった。摘出した浅葉 内に 2 つの腫瘍が認められた。いずれも弾性軟の腫瘤で, 比較的厚い被膜を有する割面が灰白色で囊胞状のもの （腫瘍(1)）と，薄い被膜を有するもの（腫瘍(2)）であった。 病理組織学的所見: 腫瘍(1)では, 線維性被膜に团まれ, 腫瘍細胞は充実性あるいは索状に配列し増殖している. 腫瘍細胞の辺縁側では上皮様配列を示す。核の大小およ び分裂像は認めない（図 4). 以上より基底細胞腺腫の充
実型と診断された。腫瘍(2)では，被膜形成がみられず， リンパ組織のなかに二層性の上皮細胞で囲まれた霊胞が 認められた（図 5)。こちらはワルチン腫瘍と診断された。 術後経過：一過性の顔面神経麻痺も認めず，経過良好 であったため退院となり，以後外来で経過観察中である が再発等は認めていない。

\section{考察}

基底細胞腺腫 (basal cell adenoma) は, 1967 年に Kleinsasser ら”) が “皮膚の基底細胞癌（basal cell carcinoma）に 形態的に類似した唾液腺腫瘍”を “basal zell adenoma” として記載したのが最初である. 以来, 1972 年の耳下腺 腫瘍 WHO 分類では単形腺腫 (monomorphic adenoma) の 亜分類に, 1991 年の新分類では独立した腫瘍として分類 されている。

本腫瘍は比較的まれな腫痬であり, Kleinsasser ら ${ }^{1)}$ は その頻度を全唾液腺腫瘍中 $2 \%$, Thackray ら ${ }^{2)}$ は 1.8\%, 長尾 ${ }^{3)}$ は $5.3 \%$ としている. 好発年齢は 50 歳以上で，女 性にやや多いとされている。好発部位は耳下腺が最も多 $<$, 上口唇の小唾液腺, 顎下腺, 舌下腺, 軟口蓋, 硬口 蓋，煩粘膜にも報告がみられる4)。

肉眼的には円形から卵円形の弾性硬の腫溜で，表面は 薄い線維性被膜により覆われ，断面は灰白充実性である が時に漿液性の内容液を含む囊胞を認めることがあ る5).

病理組織学的には, 充実型 (solid type), 索状型 (tubular type）, 腺管型（trabecular type）, 膜様型（membranous type)の 4 亜型に分類され，充実型が最も多いとされてい るが，これらが混在することも多い。腫瘍細胞巣は充実 性で細胞層の外層の腫瘍細胞は 1 列に配列を示し，核の 観兵式配列を示す。また，細胞巣の中心部は腺管形成や ま机に扁平上皮への分化傾向を示すこともあり，囊胞形 成，腺様囊胞構造，偽腺管構造を伴うこともある。銀染 色では肥厚した基底膜様構造が染色され，特徴的な像を 示すとされている゙3.

治療は手術が基本であり，完全摘出されていれば予後 は良好とされているが，再発・悪性化の報告もあり677， 被膜を含めた完全摘出と経過観察が重要である.

耳下腺腫瘍の両側発生はまれで, Turnbull ら 87 によ ると全耳下腺腫瘍症例 1805 例中 24 例 (1.3\%), Catania ら ${ }^{9)}$ によると 544 例中 3 例 (0.6\%), Byrne ら ${ }^{10)}$ によると 231 例中 8 例 $(3.5 \%)$, 渡辺ら ${ }^{11)}$ によると 212 例中 13 例 
（6.1\%）と報告されている，一般に，両側に発生する耳 下腺腫瘍中ではワルチン腫瘍が 50 ～85\%を占め, また ワルチン腫瘍中 5 ～ $15 \%$ が両側に発生するとされている. そのほか両側に発生する腫瘍には多形腺腫, 腺房細胞癌 が知られている。

単一耳下腺内に組織型の異なる腫瘍が存在することは 非常にまれで, Janecka ら ${ }^{12)}$ は耳下腺腫瘍約 2000 例中 7 例 $(0.4 \%)$ のみであったと報告している. 7 例中，一方 がワルチン腫瘍であったものは 6 例, 多形腺腫であった ものは 5 例であった.この 2 種の腫瘍の組み合わせは 4 例 $(57 \%)$ であり, 残り 3 例（43\%） は悪性腫瘍（粘表 皮癌 2 例, 腺癌 1 例）との合併であった. Gnepp ら ${ }^{13)}$ は 単一耳下腺に複数の腫瘍が発生した症例 25 例の検討を 行っている. 25 例中，一方がワルチン腫瘍であったもの は 17 例, 多形腺腫であったものは 10 例であった. ワル チン腫瘍と多形腺腫が混在した例が 6 例で最多 $(24 \%)$ であり，悪性腫瘍との合併は 6 例（24\%）であった．同 様に，假谷ら ${ }^{14)}$ も多発性耳下腺良性腫瘍 29 例の検討を 行っているが,多形腺種とワルチン腫瘍の混在が 20 例で 約 $70 \%$ を占めている．以上のことから，多発性耳下腺腫 瘍例では, ワルチン腫腸, 多形腺腫を念頭に置き，また 悪性腫瘍の混在にも注意を払う必要があると考えられ た.

本症例では両側の耳下部腫脹を同時期に自覚し，画像 検查でも両側耳下腺腫場が認められた。増大傾向のあっ た右側のみ手術が施行され，病理組織検查により基底細 胞腺腫と診断された。左側は経過観察されていたが増大 傾向が認められたため手術が施行され, 基底細胞腺腫と ワルチン腫瘍が混在していた.

基底細胞腺腫の両側発生例はまれであり，われわれが 渉猟し得た限りでは国内外 9 例15) 23) のみであった。 た一側耳下腺に基底細胞腺腫とワルチン腫瘍が発生した という報告は，3 例 1324425) のみであった。本症例のよう に両側耳下腺に基底細胞腺腫が発生し，また同一耳下腺 に 2 種類の良性腫瘍が存在した症例報告はなく，きわめ てまれな症例であると考えられた。

現在，外来で経過観察中であるが，再発等は認めてい ない.

\section{まとめ}

1）両側耳下腺に基底細胞腺腫が発生し,また一側耳下 腺に同時にワルチン腫揚が存在したきわめてまれな 1 例
を経験した。

2）渉猟し得た限りでは, 両側基底細胞腺腫症例は国内 外 9 例で，一側に基底細胞腺腫とワルチン腫瘍が同時に 存在した症例は 3 例であった。本症例と同様の報告はな く,きわめてまれな 1 例と考えられた。

3）耳下腺腫瘍を認めた場合は, 反対側も十分な検索お よび経過観察が必要と思われた。 また，多発性耳下腺腫 場の場合, 悪性腫瘍の混在にも注意する必要があると考 えられた。

本論文の要旨は第 275 回日本耳鼻咽喉科学会大阪地方連合会 （2000 年 12 月，大阪市）において口演した.

稿を終えるにあたり, 病理学上の御教授を頂いた大阪医科大 学病院病理部 辻 求先生に深く感謝の意を表します.

\section{参考文献}

1) Kleinsasser $\mathrm{O}$ and Klein $\mathrm{HJ}$ : Basalzelladenome der Speicheldrusen. Arch Klin Exp Ohren Nasen Kehlkopfheilk 189:302 316, 1967.

2) Thackray AC and Lucas RB : Tumors of the major salivary glands. Atlas of Tumor Pathology. Second Series Fascicle 10 (ed by Firminger HI). pp 14, Armed Forces Institute of Pathology, Washington, DC, 1974.

3) 長尾孝一: 唾液腺. 外科病理学 (石川栄世, 遠城寺宗知編). $145 \sim 173$ 頁, 文光堂, 東京, 1999 .

4）大塚明弘, 鈴木俊哉, 佐藤圭司, 他：両側性副咽頭間隙腫 瘍例. 耳鼻臨床 $91: 63 \sim 67,1998$.

5) Luna MA and Mackay B : Basal cell adenoma of the parotid gland; case report with ultrastructural observations. Cancer 37 : 1615 1621, 1976.

6）中川雅文, 竹澤裕之, 渡辺雅子, 他 : 顎下腺に発生した基 底細胞腺腫の 1 例. 耳鼻 $43: 590 \sim 593,1997$.

7) Nagao T, Sugano I, Ishida $Y$, et al. : Carcinoma in basal cell adenoma of the parotid gland. Pathol Res Pract $193: 171 \sim$ $178,1997$.

8) Turnbull $\mathrm{AD}$ and Frazell EL : Multiple tumors of the major salivary glands. Am J Surg $118: 787 \sim 789,1969$.

9) Catania VC, Bandieramonte G and Salvadori B : Bilateral tumors of the parotid glands. Tumori $61: 39 \sim 43,1975$.

10) Byrne $M N$ and Spector JG : Parotid masses; evalution, analysis, and current management. Laryngoscope $98: 99 \sim 105$, 1988.

11）渡辺哲生，一宮一成，鈴木正志，他：当科における両側性 耳下腺腫瘍症例の検討. 日耳鼻 $102 ： 1169 \sim 1174 ， 1999$.

12) Janecka IP, Perzin KH and Sternschein MJ : Rare synchronous parotid tumors of different histologic types. Plast Reconstr 
Surg $72: 798 \sim 802,1983$.

13) Gnepp DR, Schroeder $W$ and Heffner $D$ : Synchronous tumors arising in a single salivary gland. Cancer $63: 1219 \sim 1224$, 1989.

14）假谷 伸, 赤木博文, 結縁晃治, 他 : 同一耳下腺内に同時 に 2 種類の良性腫瘍を認めた 1 症例. 耳喉頭頸 $68: 312 \sim$ 316, 1996.

15) Reingold IM, Keasbey LE and Graham JH : Multicentric dermal-type cylindromas of the parotid glands in a patient with florid turban tumor. Cancer $40: 1702 \sim 1710,1977$.

16）加藤高行, 内藤準哉, 金子敏郎, 他 : 両側耳下腺に原発し た Basal cell adenoma の 1 例. 癌の臨床 29:147 151, 1983.

17）黑野祐一, 藤吉達也, 梅原豊治, 他 : 両側耳下腺腫瘍一多 発性基底細胞腺腫の 1 例一. 耳鼻臨床 $77: 423 \sim 428,1984$.

18) Herbst EW and Utz $W$ : Multifocal dermal-type basal cell adenomas of parotid glands with co-existing dermal cylindromas. Virchows Arch A Pathol Anat Histopathol $403: 95 \sim 102$, 1984.

19）鈴木茂憲, 赤池徹哉, 菅野秀貴, 他：両側耳下腺に発生し た基底細胞腺腫の一症例. 耳鼻臨床 補 83:103 107, 1995.

20) Zarbo RJ, Ricci A Jr, Kowalczyk PD, et al. : Intranasal dermal analogue tumor (membranous basal cell adenoma); ultrastruc- ture and immunohistochemistry. Arch Otolaryngol 111:333 337, 1985.

21) Schmidt KT, Ma A, Goldberg R, et al. : Multiple adnexal tumors and a parotid basal cell adenoma. J Am Acad Dermatol $25: 960 \sim 964,1991$.

22) Issing PR : Bilaterales Basalzelladenom der Parotis und Multiple Zylindrome der Haut. Ein syndromaler Zusammenhang? Laryngorhinootologie $78: 155 \sim 159,1999$.

23) Katsuno S, Ishii K, Otsuka A, et al. : Bilateral basal-cell adenomas in the parotid glands. J Laryngol Otol $114: 83 \sim 85$, 2000.

24) Goh PM and Cheah E : Synchronous tumors of the parotid gland with different histology. Br J Oral Maxillofac Surg 27 : $198 \sim 202,1989$.

25）清水義友, 長谷川博雅, 松島正和, 他: 腺リンパ腫（ワル チン腫瘍）と基底細胞腺腫が同側耳下腺に合併した 1 例. 日大医誌 $56: 334 \sim 340,1997$.

原稿受付：平成13年12月27日 原稿採択：平成14年 4 月 24 日 別刷請求先 : 吉村勝弘 厂569-8686 高槻市大学町2-7 大阪医科大学耳鼻咽喉科学教室 